\title{
Nomenclatural notes in Membracidae (Homoptera): a new name for Bordonia Sakakibara ${ }^{1}$
}

\begin{abstract}
Bordoniana is here proposed as a new name for Bordonia Sakakibara, 1997 (praeoc.) - non Bordonia Cobos, 1978 (Coleoptera, Buprestidae) -, and, consequently, the following changes: Bordoniana venezuelana (Sakakibara, 1979) comb.n.; B. clypeata (Sakakibara, 1997) comb.n.; B. majuscula (Sakakibara, 1997) comb.n.; B. nigricosta (Goding, 1926) comb.n.; B. virescens (Funkhouser, 1940) comb.n..

KEY WORDS. Homoptera, Membracidae, nomenclature, taxonomy
\end{abstract}

Albino M. Sakakibara ${ }^{2}$

\section{Bordoniana nom.n.}

Bordonia Sakakibara, 1997: 665 (Type species: B. venezuelana Sakakibara, 1997) praeoc. by Bordonia Cobos, 1978: 34 (Coleoptera, Buprestidae).

SAKAKIBARA (1997) described Bordonia as a genus of Homoptera-Membracidae-Smiliinae-Acutalini. It was found however, that this name had already been used by COBOS (1978) to designate a genus of Coleoptera-Buprestidae. It is here proposed, Bordoniana, as a new substitution name. As a result, the following changes are introduced:

Bordoniana venezuelana (Sakakibara, 1997) comb.n.

Bordonia venezuelana Sakakibara, 1997: 667

Bordoniana clypeata (Sakakibara, 1997) comb.n.

Bordonia clypeata Sakakibara, 1997: 667

Bordoniana majuscula (Sakakibara, 1997) comb.n.

Bordonia majuscula Sakakibara, 1997: 668

Bordoniana nigricosta (Goding, 1926) comb.n.

Bordonia nigricosta; Sakakibara, 1997: 670

Bordoniana virescens (Funkhouser, 1940) comb.n.

Bordonia virescens; Sakakibara, 1997: 670

ACKNOWLEDGEMENT.I would like to express my thanks to Carlos Bordón who discovered the homonymy and provided me the reprint of A. Cobos. Also to the Zoological Record that informed me about the existence of a homonym and giving me a precise reference of it.

1) Contribuição número 1133 do Departamento de Zoologia, Universidade Federal do Paraná.

2) Departamento de Zoologia, Universidade Federal do Paraná. Caixa Postal 19020, 81531-990 Curitiba, Paraná, Brasil. Bolsista do CNPq. 


\section{REFERENCES}

CoBos, A. 1978. Ensayo sobre los géneros de la subfamilia "Polycestinae" (Coleoptera, Buprestidae). Eos 54: 15-94.

SAKAKIBARA, A.M. 1997. The tribe Acutalini Fowler (Homoptera, Membracidae, Smiliinae): new genera, new species, and some nomenclatural changes. Revta bras. Zool. 14 (3): 659-674 [1998].

Recebido em 18.III.1999; aceito em 10.VI.1999. 